\title{
THE USE OF MICROSATELLITE MARKERS TO STUDY GENETIC DIVERSITY IN INDONESIAN SHEEP
}

\author{
Jakaria' $^{1}$, M.S.A. Zein ${ }^{2}$, S. Sulandari ${ }^{2}$, Subandriyo ${ }^{3}$ and Muladno ${ }^{1}$ \\ ${ }^{1}$ Faculty of Animal Science, Bogor Agricultural University, \\ Jl Agatis, Darmaga Campus, Bogor 16680 - Indonesia \\ ${ }^{2}$ Indonesian Institute of Sciences, Jl. Raya Bogor Km 46, Cibinong 16911, Bogor - Indonesia \\ ${ }^{3}$ Indonesian Center for Animal Science Research and Development (ICASRD), \\ Jl. Veteran III PO Box 221, 16002, Bogor - Indonesia \\ Correspondence E-mail: jakaria@ipb.ac.id
}

Received January 9, 2012; Accepted February 18, 2012

\begin{abstract}
ABSTRAK
Tujuan penelitian ini adalah mempelajari keragaman genetik populasi domba di Indonesia menggunakan penciri DNA mikrosatelit. Sebanyak 18 lokus DNA mikrosatelit digunakan untuk menentukan genotipe populasi domba Indonesia. Sampel darah domba yang digunakan sebanyak 200 ekor berasal dari populasi domba garut tipe tangkas, domba garut tipe daging, domba purbalingga, domba batur dan domba jember diektraksi DNA total dengan menggunakan metode salting out. Data lokus DNA mikrosatelit dianalisis menggunakan program POPGENE 3.2. Hasil penelitian menunjukkan bahwa diperoleh sebanyak 180 alel dari 17 lokus DNA mikrosatelit, sedangkan rataan jumlah alel adalah 10 alel (6 sampai 18 alel) dari lima populasi domba Indonesia (domba garut tipe tangkas, domba garut tipe daging, domba purbalingga, domba batur dan domba jember). Nilai heterosigositas observasi (Ho) dan heterosigostas harapan ( $\mathrm{He}$ ) diperoleh masing-masing 0,5749 dan 0,6896, sedangkan nilai genetik diferensiasi untuk inbreeding antar populasi ( $\mathrm{F}_{\mathrm{IS}}$ ), dalam populasi (F $\mathrm{F}_{\text {IT }}$ ) dan rataan diferensiasi genetik (Fsт) masing-masing 0,1006; 0,1647 dan 0,0712. Jarak genetik dan pohon genetik menunjukkan bahwa populasi domba Indonesia berbeda antara populasi domba garut tipe tangkas, domba garut tipe daging, domba purbalingga, domba batur dan domba jember. Berdasarkan hasil penelitian dapat disimpulkan bahwa diperlukan strategi program pemuliaan, pelestarian dan pemanfaatan secara berkelanjutan pada setiap populasi domba di Indonesia.
\end{abstract}

Kata-kata kunci: domba Indonesia, penciri DNA mikrosatelit, keragaman genetik

\begin{abstract}
The purpose of this research was to study genetic diversity in Indonesian sheep population using microsatellite markers. A total of 18 microsatellite loci have been used for genotyping Indonesian sheep. Total sheep blood 200 samples were extracted from garut sheep of fighting and meat types, purbalingga sheep, batur sheep and jember sheep populations by using a salting out method. Microsatellite loci data were analyzed using POPGENE 3.2 software. Based on this study obtained 180 alleles from 17 microsatellite loci, while average number of alleles was 6.10 alleles (6 to 18 alleles) from five Indonesian sheep populations (garut sheep of fighting type, garut sheep of meat type, purbalingga sheep, batur sheep and jember sheep population). The average of observed heterozygosity (Ho) and expected heterozygosity $(\mathrm{He})$ values were 0.5749 and 0.6896 , respectively, while the genetic differentiation for inbreeding among population (FIS), within population (FIT) and average genetic differentiation (FsT) were $0.1006,0.1647$ and 0.0712 , respectively. Genetic distance and genetic tree showed that Indonesian sheep population was distinct from garut sheep of fighting and meat types, purbalingga sheep, batur sheep and jember sheep population. Based on this results were needed a strategy for conservation and breeding programs in each Indonesian sheep population.
\end{abstract}

Keywords: Indonesian sheep, microsatellite marker, genetic diversity

\section{INTRODUCTION}

Indonesian sheep is generally maintained extensively by small holder farmers and only a small part reared intensively. Besides that, sheep breeding is an important livestock sector, as a 
major source of meat and small part as social culture. Indonesia has two types of sheep which are very popular throughout the country, i.e. thin tail type and fat tail type sheep (Devendra and McLeroy, 1992). In addition, there are also fighting type sheep, so called garut sheep. Indonesian thin and fat tail sheep have several advantages; especially they are well adapted to the hard environment, able to utilize low-quality feed, prolific (Inounu et al., 1986), early puberty (Sutama et al., 1988) and resistance to internal parasites (Romjali et al., 1998).

As one of the Indonesian animal genetic resources, sheep plays an important role for small holder farmers. So, it is expected that sheep rearing may provide benefits for food availability needed, agricultural and social development of society in the future. Moreover, genetic attention on Indonesian sheep is still very limited. According to Baumung et al. (2004), DNA microsatellite is one of the popular markers used to estimate genetic diversity in livestock. DNA microsatellite sequences are valuable genetic markers due to their dense distribution in the genome, great variation, co-dominant inheritance and easy genotyping. In recent years, they have been extensively used in parentage testing, linkage analyses, population genetics and other genetic studies (Goldstein and Pollock, 1997).

Several studies have reported that DNA microsatellite marker have been widely used to study genetic diversity in Spanish sheep (Arranz et al., 2001), European sheep (Peter et al., 2007), meat type sheep in China (Chen et al., 2009) and Ganjam sheep (Arora et al. 2010). Based on the lack of genetic information about garut sheep of fighting and meat types, purbalingga sheep, batur sheep and jember sheep populations as Indonesian local sheep, so microsatellite markers became one of the reasons where this research was conducted to determine the genetic diversity in Indonesian sheep population especially garut sheep of fighting type, garut sheep of meat type, purbalingga sheep, batur sheep and jember sheep populations.

\section{MATERIAL AND METHODS}

Two hundred blood samples of unrelated animals were collected from five sheep populations in Garut regency of West Java, Purbalingga and Banjarnegara regencies in Central Java, and Jember regency in East Java
(Table 1). Blood sample was taken through the vena jugular's and preserved in the magic buffer (anticoagulant, antifungal and antibacterial), and then stored in freezer.

Sheep total genomic was extracted by using salting-out method (Mburu and Hanotte, 2005). A total of 18 microsatellite markers used in this study were selected from the International Society for Animal Genetics (ISAG) lists (FAO, 1998) as follows ILSTS05, MCM527, SRCPSP05, OarFCB128, HUJ616, OarHH47, ILSTS11, DYMS1, BM8125, OarFCB226, OarAE129, OarJMP29, SRCRSP9, MAF214, OarCP34, OarFBC203, MAF09, MAF65, respectively (Table 2). Amplification of these 18 microsatellite loci from sheep genomic DNA of each individual was carried by using ABsys PCR machine based a manual of microsatellite genotyping with special reference to livestock population genetics protocol (Mburu and Hanotte 2005). Genotyping is done using the reaction multi-loading/coloading in ABI3130XL automatic sequencer machine. Sample analyzed was divided into three co-loading. Each co-loading consists of six sets of primer (PCR product) with four colors according to the label used. Co-loading 1 consists ILSTS5, MCM527, SRCPSP05, OarFCB128, HUJ616 and OarHH47 loci. Co-loading 2 consists ILSTS11, DYMS1, BM8125, OarFCB226, OarAE129 and OarJMP29 loci. Co-loading 3 consists SRCRSP9, MAF214, OarCP34, OarFCB203, MAF09 and MAF65 loci.

Allele identification of microsatellite loci were analyzed using GeneMapper software (version 3.7, Applied Biosystems). Number of alleles (NA) of each locus and the number of effective alleles (NE) per locus, observed heterozygosity values $\left(\mathrm{H}_{\mathrm{o}}\right)$ and expected heterozigosity $\left(\mathrm{H}_{\mathrm{e}}\right), \mathrm{F}$ statistics $\left(\mathrm{F}_{\mathrm{IS}}, \mathrm{F}_{\mathrm{IT}}, \mathrm{F}_{\mathrm{ST}}\right)$ and genetic distance were calculated using GENEPOP software (V3.2) (Raymond and Rousset, 2001). The genetic tree constructed using UPGMA (Unweighted Pair Group Method with Arithmetic mean) method (Nei et al., 1983).

\section{RESULTS AND DISCUSSION}

From 18 loci of DNA microsatellite amplified on five sheep populations (garut sheep of fighting type, garut sheep of meat type, purbalingga sheep, batur sheep and jember sheep population), only one locus (OARHH47 locus) did not successfully amplified (Figure 1 and 2). 
Table 1. Summary of Sheep Population Samples

\begin{tabular}{llccc}
\hline Population & \multicolumn{1}{c}{ Location } & Type & Utility & Blood Sample \\
\hline Garut 1 & $\begin{array}{l}\text { Small holder farmer, Wanaraja-Garut } \\
\text { regency-West Java. }\end{array}$ & Thin tail & Fighting & 40 \\
Garut 2 & $\begin{array}{l}\text { Small holder farmer, Wanaraja-Garut } \\
\text { regency-West Java. }\end{array}$ & Thin tail & Meat & 40 \\
Purbalingga & $\begin{array}{l}\text { Small holder farmer, Kaligondang- } \\
\text { Purbalingga, Central Java. }\end{array}$ & Thin tail & Meat & 40 \\
Batur & $\begin{array}{l}\text { Small holder farmer, Batur- } \\
\text { Banjarnegara,Central Java. }\end{array}$ & Fat tail & Meat & 40 \\
Jember & UPT Garahan-Jember-East Java & Fat tail & Meat & 40 \\
\hline
\end{tabular}

Seventeen of DNA microsatellite loci used, 180 alleles were found in five Indonesian sheep populations. The number of alleles per locus (NA) varied from six alleles (SRCRSP5 and BM8125 loci) to 18 alleles (OARFCB304 locus) with the average and standard deviation 10.6 and 3.7, respectively, for all populations. The number of alleles (NA) and effective allele number (NE) in the total population are presented in Table 3, while the average number of alleles (MNA) and the average effective number of alleles (MNE) are presented in Table 4.

These results showed high average number of alleles (10.6) in all Indonesian sheep population breeds, while the number of alleles between population is lower (6.4) than all populations. The average number effective of allele is high (3.7) in jember sheep population, but low (2.7) in garut sheep of fight type population. The average number of alleles in each population is not different significantly (6.2 to 6.5). The average and standard deviation of the observed heterozygosity $\left(\mathrm{H}_{\mathrm{o}}\right)$ and expected heterozygosity $\left(\mathrm{H}_{\mathrm{e}}\right)$ in Indonesian sheep populations are $0.5749 \pm 0.1236$ and $0.6878 \pm 0.1065$, respectively (Table 5). The average heterozygosity value was high in Indonesian sheep population based on the observed $\left(\mathrm{H}_{\mathrm{o}}\right)$ and the expected heterozygosity $\left(\mathrm{H}_{\mathrm{e}}\right)$ values. This result indicated that the genetic diversity within population of Indonesian sheep were still high.

Seventeen microsatellite loci were used effectively to explain the genetic diversity between and within Indonesian sheep populations. Based on the seventeen microsatellite loci used in this study, 9 loci have number of alleles (NA) more than 10 alleles, i.e. MCM527, HUJ616, DYMS1， OARFCB226, OARAE129, OARJMP29, MAF214, OARFCB304 and MAF209, loci. High number of alleles in each microsatellite locus would affect genetic variability (polymorphic) in Indonesian sheep that displayed on all population. Eight loci having less than 10 alleles are ILSTS05, SRCRSP5, OARFCB128, ILSTS11, SRCRSP9, BM8125, OARCP34, and MAF65 loci. This result showed that Indonesian sheep population has the allele number higher then Ganjam sheep population. Arora et al. (2010) reported that 137 alleles from 25 loci of microsatellite DNA marker were found in Ganjam sheep.

$\mathrm{F}$ statistics $\left(\mathrm{F}_{\mathrm{IS}}, \mathrm{F}_{\mathrm{IT}}\right.$ and $\left.\mathrm{F}_{\mathrm{ST}}\right)$ analysis showed that inbreeding rate between $\left(\mathrm{F}_{\mathrm{IS}}\right)$ and within $\left(\mathrm{F}_{\mathrm{IT}}\right)$ populations are $0.1006(10.06 \%)$ and 0.1647 $(16.47 \%)$ respectively, whereas genetic differentiation $\left(\mathrm{F}_{\mathrm{ST}}\right)$ between population is 0.0712 $(7.12 \%)$ (Table 6). High genetic diversity in Indonesian sheep population indicated nonappearance of an intensive selection program and there is no depression inbreeding. The inbreeding rate value on between $\left(\mathrm{F}_{\mathrm{IS}}\right)$ and within $\left(\mathrm{F}_{\text {IT }}\right)$ population are $0.1006(10.06 \%)$ and 0.1647 $(16.47 \%)$, respectively, which is relatively low. In contrast, the results of inbreeding rate in the Chinese sheep populations (Dorset, Texel, BlackSufolk, Tan, Han, hybrid TH) are 0.5272 $(52.72 \%)$ and $0.5602(56.02 \%)$, for $\mathrm{F}_{\text {IS }}$ and $\mathrm{F}_{\text {IT }}$ respectively, whereas the expected heterozygosities $(0.8177)$ were higher than the observed heterozygosities (0.3838), showing that homozygous individuals are more than common, and inbreeding is serious in the tested populations (Chen et al., 2009). In contrast to our study results 
Table 2. The Primer Sequences, Label and Temperature Annealing of the Used Microsatellite Marker

\begin{tabular}{|c|c|c|c|c|c|}
\hline Locus Name & Sequences 5 ' $\rightarrow$ 3' Forward/ Reverse & Label & $\begin{array}{c}\mathrm{Ta} \\
\left({ }^{\circ} \mathrm{C}\right)\end{array}$ & $\begin{array}{l}\text { Allele } \\
\text { Size } \\
\text { (bp) }\end{array}$ & $\begin{array}{c}\text { Chromosomal } \\
\text { Location }\end{array}$ \\
\hline \multirow[t]{2}{*}{ ILSTS005 } & GGAAGCAATGAAATCTATAGCC & 6FAM & 55 & $174-218$ & 7 \\
\hline & TGTTCTGTGAGTTTGTAAGC & & & & \\
\hline \multirow[t]{2}{*}{ MCM527 } & GTCCATTGCCTCAAATCAATTC & NED & 56 & $165-187$ & 5 \\
\hline & AАACCACTTGACTACTCCCCAА & & & & \\
\hline \multirow[t]{2}{*}{ SRCRSP5 } & GGACTCTACCAACTGAGCTACAAG & VIC & 55 & $126-158$ & 18 \\
\hline & GTTTCTTTGAAATGAAGCTAAAGCAATGC & & & & \\
\hline \multirow[t]{2}{*}{ OarFCB128 } & ATTAAAGCATCTTCTCTTTATTTCCTCGC & 6FAM & 56 & $96-130$ & 2 \\
\hline & CAGCTGAGCAACTAAGACATACATGCG & & & & \\
\hline \multirow[t]{2}{*}{ HUJ616 } & TTCAAACTACACATTGACAGGG & PET & 58 & $114-160$ & 13 \\
\hline & GGACCTTTGGCAATGGAAGG & & & & \\
\hline \multirow[t]{2}{*}{ OarHH47 } & TTTATTGACAAACTCTCTTCCTAACTCCACC & NED & 56 & $130-152$ & 18 \\
\hline & GTAGTTATTTAAAAAAATATCATACCTCTTAAGG & & & & \\
\hline \multirow[t]{2}{*}{ ILSTS11 } & GCTTGCTACATGGAAAGTGC & 6FAM & 61 & 256-294 & 9 \\
\hline & CTAAAATGCAGAGCCCTACC & & & & \\
\hline \multirow[t]{2}{*}{ DYMS1 } & AACAACATCAAACAGTAAGAG & NED & 56 & $159-211$ & 20 \\
\hline & CATAGTAACAGATCTTCCTACA & & & & \\
\hline \multirow[t]{2}{*}{ BM8125 } & CTCTATCTGTGGAAAAGGTGGG & NED & 52 & $110-130$ & 1 \\
\hline & GGGGGTTAGACTTCAACATACG & & & & \\
\hline \multirow[t]{2}{*}{ OarFCB226 } & CTATATGTTGCCTTTCCCTTCCTGC & VIC & 58 & $119-153$ & 2 \\
\hline & GTGAGTCCCATAGAGCATAAGCTC & & & & \\
\hline \multirow[t]{2}{*}{ OarAE129 } & AATCCAGTGTGTGAAAGACTAATCCAG & 6FAM & 56 & $133-159$ & 5 \\
\hline & GTAGATCAAGATATAGAATATTTTTCAACACC & & & & \\
\hline \multirow[t]{2}{*}{ OarJMP29 } & GTATACACGTGGACACCGCTTTGTAC & PET & 56 & $96-150$ & 24 \\
\hline & GAAGTGGCAAGATTCAGAGGGGAAG & & & & \\
\hline \multirow[t]{2}{*}{ SRCRSP9 } & AGAGGATCTGGAAATGGAATC & 6FAM & 55 & $99-135$ & 12 \\
\hline & GCACTCTTTTCAGCCCTAATG & & & & \\
\hline \multirow[t]{2}{*}{ MAF214 } & GGGTGATCTTAGGGAGGTTTTGGAGG & 6FAM & 58 & 174-282 & 16 \\
\hline & AATGCAGGAGATCTGAGGCAGGGACG & & & & \\
\hline \multirow[t]{2}{*}{ OarCP34 } & GCTGAACAATGTGATATGTTCAGG & PET & 57 & $112-130$ & 3 \\
\hline & GGGACAATACTGTCTTAGATGCTGC & & & & \\
\hline \multirow[t]{2}{*}{ OarFCB304 } & CCCTAGGAGCTTTCAATAAAGAATCGG & VIC & 58 & $150-188$ & 19 \\
\hline & CGCTGCTGTCAACTGGGTCAGGG & & & & \\
\hline \multirow[t]{2}{*}{ MAF209 } & GATCACAAAAAGTTGGATACAACCGTGG & VIC & 65 & $109-135$ & 17 \\
\hline & TCATGCACTTAAGTATGTAGGATGCTG & & & & \\
\hline \multirow[t]{2}{*}{ MAF65 } & AAAGGCCAGAGTATGCAATTAGGAG & NED & 56 & $123-163$ & 15 \\
\hline & ССАСТССТССТGAGAATATAACATG & & & & \\
\hline
\end{tabular}

$6 \mathrm{FAM}=$ blue color, $\mathrm{NED}=$ yellow color, $\mathrm{VIC}=$ green color and $\mathrm{PET}=$ red color, $\mathrm{Ta}=$ temperature annealing

showed that the observed $\left(\mathrm{H}_{\mathrm{o}}\right)$ and expected $\left(\mathrm{H}_{\mathrm{e}}\right)$ heterozygosity on Indonesian native sheep populations were similar.
Genetic tree constructed on the basic of genetic distances among populations are divided into four major groups namely, garut sheep (thin 


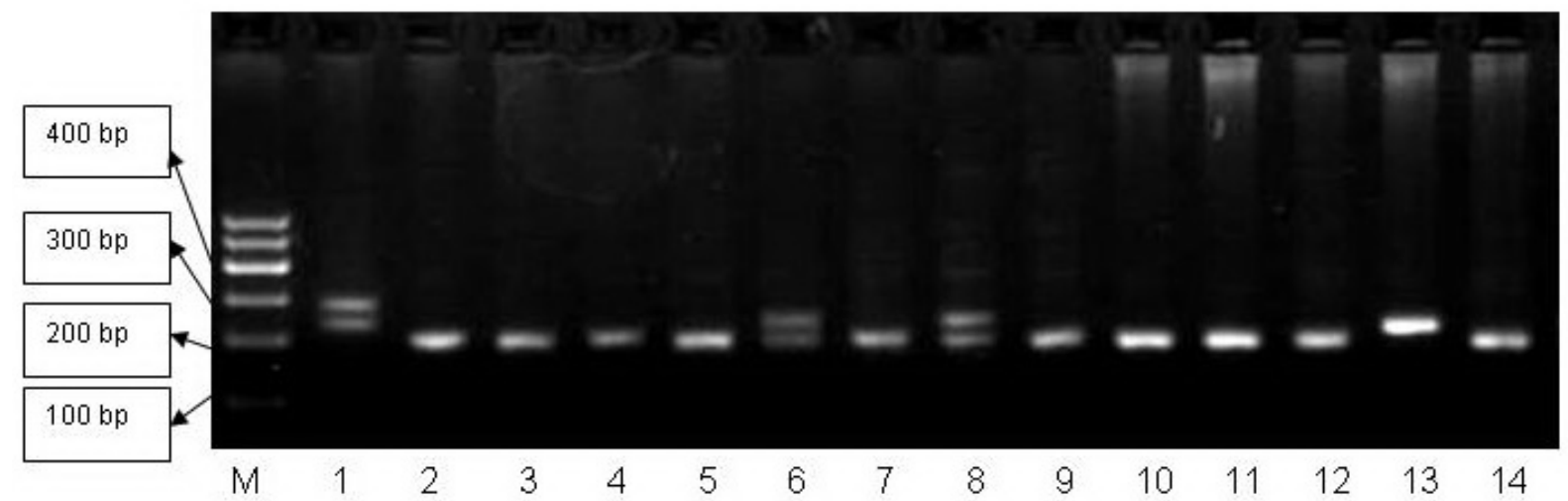

Figure 1. PCR Product Example of DNA Microsetellite MAP214 Locus by 1.5\% Agarose Gel Electrophoresis. M: Marker 100 bp; Line 1-14 : Sample number
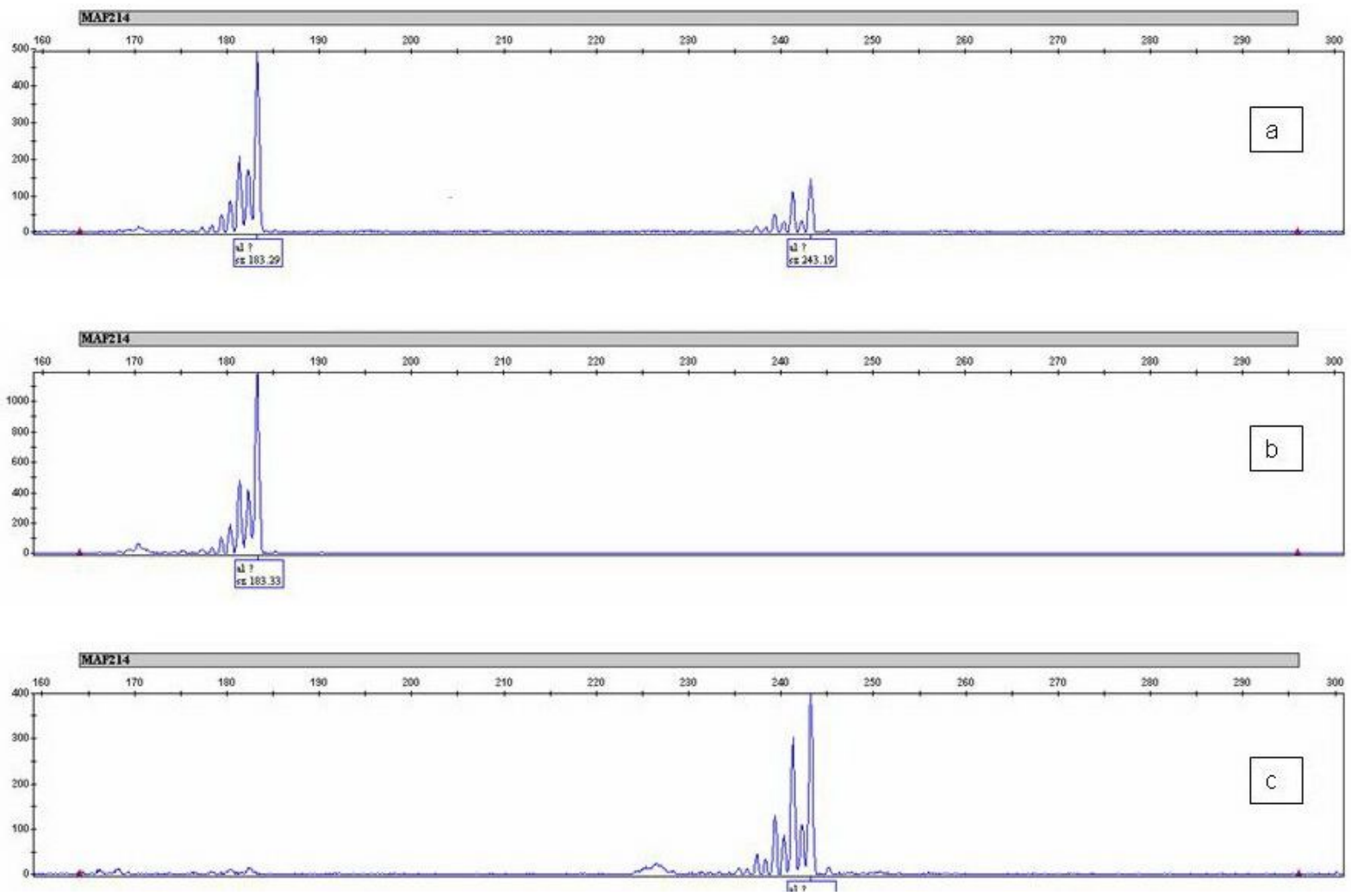

Figure 2. Genotyping Result Example of DNA Microsatellite MAF214 Locus by Using ABI3130XL Sequencer Automatice Machine. (a): 183/243 Genotype Heterozygote; (b) 183/183 Homozygote Genotype; (c) 243/243 Homozygote Genotype

tail sheep), purbalingga sheep (thin tail sheep) and then batur and jember sheep (fat tail sheep) showed that exactly Indonesian sheep populations were distinct (Table 7; Figure 3). Garut sheep population (fight and meat types) and jember sheep population (fat tail type) had a distant of genetic tree, whereas the closest genetic distance was found in both garut sheep population, namely fighting and meat types sheep populations.

Genetic tree in five Indonesian sheep 
Table 3. Number Af allele (NA) and Number Effective of Allele (NE) for 17 Loci in Indonesian Sheep Population

\begin{tabular}{lccc}
\hline Locus & Total Sample & Number of Allele & $\begin{array}{c}\text { Effective Number of } \\
\text { Allele (Ne) }\end{array}$ \\
\hline ILSTS05 & 193 & 9 & 2.1 \\
MCM527 & 188 & 13 & 4.4 \\
SRCRSP5 & 188 & 6 & 2.4 \\
OARFCB128 & 193 & 9 & 5.3 \\
HUJ616 & 193 & 14 & 2.8 \\
ILSTS11 & 185 & 7 & 2.3 \\
SRCRSP9 & 193 & 7 & 2.9 \\
DYMS1 & 182 & 15 & 4.9 \\
BM8125 & 184 & 6 & 2.2 \\
OARFCB226 & 182 & 16 & 3.6 \\
OARAE129 & 185 & 10 & 3.2 \\
OARJMP29 & 185 & 10 & 2.5 \\
MAF214 & 195 & 10 & 2.9 \\
OARCP34 & 181 & 7 & 3.4 \\
OARFCB304 & 192 & 18 & 7.9 \\
MAF209 & 192 & 14 & 5.4 \\
MAF65 & 178 & 9 & 4.0 \\
\hline Mean & 187.5 & 10.6 & 3.7 \\
St. Dev & - & 3.7 & 1.5 \\
\hline
\end{tabular}

*) total sample each locus analyzed from 200 samples

Table 4. Mean Number of Allele (MNA) and Mean Number Effective of Allele (MNE) for 17 Loci in Five Indonesian Native Sheep Populations

\begin{tabular}{lccc}
\hline Population & Total Sample*) & MNA & MNE \\
\hline Garut-1 & 37 & $6.4 \pm 2.21$ & $2.7 \pm 0.84$ \\
Garut-2 & 38 & $6.2 \pm 2.09$ & $3.1 \pm 1.09$ \\
Purbalingga & 37 & $6.4 \pm 2.37$ & $3.1 \pm 1.24$ \\
Batur & 38 & $6.4 \pm 2.26$ & $3.2 \pm 1.41$ \\
Jember & 38 & $6.5 \pm 2.45$ & $3.7 \pm 1.58$ \\
\hline
\end{tabular}

${ }^{*}$ total sample each population analyzed from 40 samples

populations showed distinctive from others. Garut sheep groups (fights and meat types) showed that genetic distance are closer to purbalingga sheep compared to jember sheep population. A genetic distance among Indonesian sheep populations was supported by the average genetic differentiation $\left(\mathrm{F}_{\mathrm{ST}}\right)(7.12 \%)$. Other studies reported that average genetic differentiation $\left(\mathrm{F}_{\mathrm{ST}}\right) 7 \%$ found in Spanish 
Table 5. Mean and Standard Deviation of Observed $\left(\mathrm{H}_{\mathrm{o}}\right)$ and Expected $\left(\mathrm{H}_{\mathrm{e}}\right)$ Heterozygosity for 17 Microsatellite Loci in Indonesian Native Sheep

\begin{tabular}{lccc}
\hline Population & Total Sample & $\mathrm{H}_{\mathrm{o}}$ & $\mathrm{H}_{\mathrm{e}}$ \\
\hline Garut-1 & 37 & $0.5389 \pm 0.1507$ & $0.6084 \pm 0.1062$ \\
Garut-2 & 38 & $0.5674 \pm 0.1509$ & $0.6353 \pm 0.1207$ \\
Purbalingga & 37 & $0.5640 \pm 0.1593$ & $0.6465 \pm 0.1173$ \\
Batur & 38 & $0.5432 \pm 0.2028$ & $0.6242 \pm 0.1682$ \\
Jember & 38 & $0.6559 \pm 0.2011$ & $0.6759 \pm 0.1418$ \\
\hline Total & 188 & $0.5749 \pm 0.1236$ & $0.6878 \pm 0.1065$ \\
\hline
\end{tabular}

*) Total sample each population success analyzed from 40 samples

Table 6. $\mathrm{F}_{\mathrm{IS}}, \mathrm{F}_{\mathrm{IT}}$ and $\mathrm{F}_{\mathrm{ST}}$ for 17 Loci in Indonesian Sheep Population

\begin{tabular}{lccc}
\hline Locus & $\mathrm{F}_{\text {IS }}$ & $\mathrm{F}_{\text {IT }}$ & $\mathrm{F}_{\text {ST }}$ \\
\hline ILSTS05 & 0.0788 & 0.1372 & 0.0634 \\
MCM527 & 0.0051 & 0.0832 & 0.0785 \\
SRCRSP5 & 0.5304 & 0.5607 & 0.0645 \\
OARFCB128 & 0.0558 & 0.1629 & 0.1135 \\
HUJ616 & 0.1203 & 0.1559 & 0.0405 \\
ILSTS11 & 0.0544 & 0.1365 & 0.0868 \\
SRCRSP9 & 0.0356 & 0.1201 & 0.0876 \\
DYMS1 & 0.0513 & 0.1080 & 0.0598 \\
BM8125 & 0.0649 & 0.1192 & 0.0580 \\
OARFCB226 & -0.0382 & 0.0174 & 0.0536 \\
OARAE129 & 0.2527 & 0.3125 & 0.0800 \\
OARJMP29 & -0.0314 & 0.0063 & 0.0366 \\
MAF214 & 0.1054 & 0.1579 & 0.0587 \\
OARCP34 & 0.0886 & 0.1591 & 0.0773 \\
OARFCB304 & 0.1496 & 0.2084 & 0.0692 \\
MAF209 & 0.0910 & 0.1506 & 0.0655 \\
MAF65 & 0.1483 & 0.2346 & 0.1013 \\
\hline Mean & 0.1006 & 0.1647 & 0.0712 \\
\hline
\end{tabular}

sheep (Arranz et al., 2001), 6.98\% in meat type sheep China (Chen et al., 2009) and 5.7\% in European sheep (Peter et al., 2007). These results showed that genetic differentiation values in Indonesian sheep population higher than Spanish sheep population, China's meat type sheep population and European sheep population, respectively.

A certainty, DNA microsatellite marker was very useful in the study of genetic diversity, genetic differentiation, and genetic tree. It can be applied widely in livestock, including Indonesian sheep population, i.e. garut sheep including garut sheep as fighting and meat types, batur sheep, 
Table 7. Genetic Distance of Five Indonesian Native Sheep Populations

\begin{tabular}{lccccc}
\hline Population & Purbalingga & Jember & Garut-1 & Garut-2 & Batur \\
\hline Purbalingga & & 0.8607 & 0.8680 & 0.8628 & 0.8421 \\
Jember & 0.1500 & & 0.7557 & 0.7630 & 0.7620 \\
Garut-1 & 0.1415 & 0.2801 & & 0.9372 & 0.8271 \\
Garut-2 & 0.1476 & 0.2705 & 0.0649 & & 0.8424 \\
Batur & 0.1719 & 0.2719 & 0.1899 & 0.1715 & \\
\hline
\end{tabular}

Nei's genetic identity (above diagonal) and genetic distance (below diagonal)

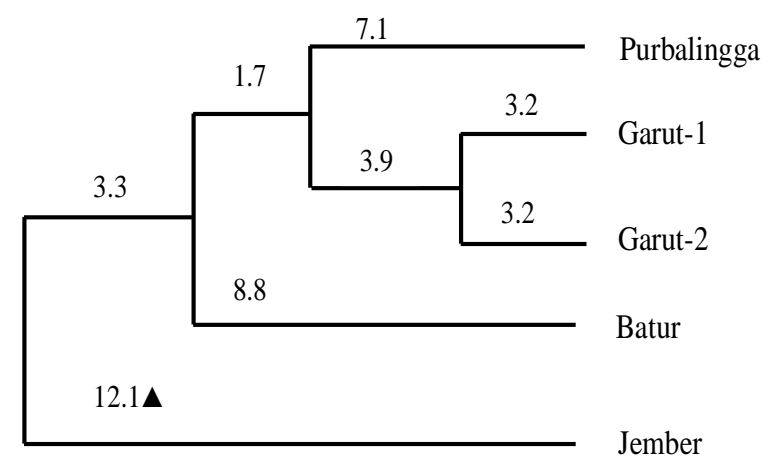

Figure 3. Dendrogram of Genetic Tree in Indonesian Sheep by using UPGMA Method, $(\mathbf{\Delta})$ : Branching Distance Value in Percentage

purbalingga sheep and jember sheep. Based on this study, it is necessary to conserve and to design appropriate breeding strategies to Indonesian sheep populations especially garut sheep (fighting and meat type), purbalingga sheep, batur sheep and jember sheep population to ensure continuity of animal genetic resources in the future.

\section{CONCLUSION}

Indonesian sheep populations have a high genetic diversity in garut sheep, purbalingga sheep, batur sheep and jember sheep populations. This result indicated can be used as basic information for utilization, conservation and genetic improvement programs in Indonesian sheep population breeds.

\section{ACKNOWLEDGMENTS}

Authors thank to IAEA (International Atomic Energy Agency) for funding this research (contract number: CRP D.3.10.25). Authors also thank to Prof. Han Jianlin for genotyping analysis in Laboratory of Livestock and Forage Genetic Resources, CAAS-ILRI JLLFGR Beijing, China. Finally, authors thank to Eryk Andreas, MSc for assisting in data analysis.

\section{REFERENCES}

Arora, R., S. Bhatia and A. Jain 2010. Morphological and genetic characterization of Ganjam sheep. Anim. Genet. Resour. 46:19.

Arranz, J. J., Y. Bayon., and F. S. Primitivo. 2001. Genetic variation at microsatellite loci in Spanish sheep. Small Rum. Res. 39:3-10.

Baumung, R., H. Simianer, and I. Hoffmann. 2004. Genetic diversity studies in farm animals - a survey. J. Anim. Breed. and Genet. 121:361-73.

Boyce, W. M., P. W. Hedrick, N. E. M. Cockett, S. Kalinowski, M. C. Penedo and R. R. Ramey. 1996. Genetic variation of major histocompatibility complex and microsatellite loci: a comparison in Bighorn sheep. Genet. 145:42-433.

Chen, R. J., Z. P. Yang, D. J. Ji, D.Y. Qu, Y. L. Li, Y.J. Mao and D. L. Huang. 2009. Analysis of genetic polymorphism in six meat sheep breeds and genetic distances between them. Czech J. Anim. Sci. 54:461-467.

Davindra, R.V. and G.B. McLeroy. 1992. Sheep Breeds. In ELBS, editor. Goat and sheep Production in the Tropics. England, Longman Group Ltd.

FAO, 1998. Secondary Guidelines for Development of National Farm Animal Genetic Resources Management Plans: Measurement of Domestic Animal Diversity (MoDAD): Recommended Microsatellite 
Markers. Food and Agriculture Organization, Rome.

Goldstein, D.B. and D. D. Pollock. 1997. Launching microsatellites: a review of mutation processes and methods of phylogenetic inference. J. Hered. 88:335-342.

Inounu, I., Subandriyo, N. Tomas, P. Sitorus, and M. Bell. 1986. Lambing characteristic of Javanese Thin-Tail ewe at Cicadas Experiment Station and under Vellage condation. J. Anim. Sci. 2:79-82.

Mason, I. L. 1980. Prolific tropical sheep FAO. Animal Production and Health Paper. FAO. Rome 17:65-74.

Mburu, D. and O. Hanotte. 2005. A practical approach to microsatellite genotyping with special renference to livestock population genetics. ILRI Nairobi, Kenya.

Nei, M., F. Tajima and Y. Tateno. 1983. Accuracy of estimated phylogenetic trees from molecular date. J. Mol. Biol. and Evol. 19:153-170.

Peter, C., M. Bruford, T. Perez, S. Dalamitra, G. Hewitt and G. Erhardt. 2007. Genetic diversity and subdivision of 57 European and Middle-Eastern sheep breeds. Anim. Genet. 38:37-44.

Raymond, M. and F. Rousset. 2001. Genepop (3.3). Population Genetics Software for Exact Tests and Ecumenicism (EB/OL) (http:www:wbiomed.curtin.edu.au/ genepop).

Romjali, E., V. S. Pandey, R.M. Gatenby, M. Doloksaribu, H. Sakul and A. Verhulst. 1998. Genetic resistence of different genotype of sheep to natural infections with gastrointestinal nematodes. Anim. Sci. 64:97-104.

Sutama, I.K., T. N. Edey and I.C. Fletcher. 1988. Study on reproduction of Javanese thin-tail ewes. Aus. Agric. Res. 39:703-711. 